\title{
Presence of depressive symptoms in medical students in a Mexican public university
}

\author{
Marco Antonio Tadeo-Álvarez, ${ }^{2}$ Claudia Daniela Munguía-Ortíz, ${ }^{2}$ Valeria Benítez-López, ${ }^{2}$ Ana María Valles-Medina, \\ Guadalupe Delgadillo-Ramos, 'Paola Michelle Flores-Castillo, ${ }^{2}$ Marcela Romo-Guardado 2,3
}

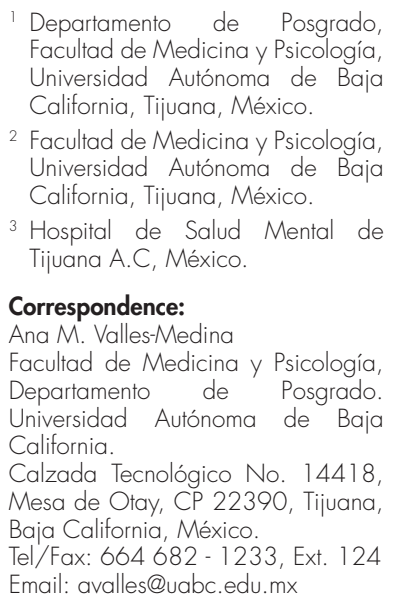

Correspondence:

Ana M. Valles-Medina

Facultad de Medicina y Psicología, Departamento de Posgrado. Universidad Autónoma de Baja California.

Calzada Tecnológico No. 14418 . Mesa de Otay, CP 22390, Tijuana, Baja California, México.

Tel/Fax: 664682 - 1233, Ext. 124

Email: avalles@uabc.edu.mx

Received: 9 October 2018

Accepted: 28 June 2019

\section{Citation:}

Tadeo-Álvarez, M. A., Munguía-Ortíz, C. D., Benítez-lópez, V., Valles-Medina, A. M., Delgadillo-Ramos, G., Flores-Castillo, P. M., \& Romo-Guardado, M. (2019). Presence of depressive symptoms in medical students in a Mexican public university. Salud Mental, 42(3), 131-136.

DOI: $10.17711 /$ SM.0185-3325.2019.017

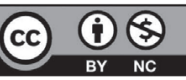

\begin{abstract}
Introduction. During their professional training, medical students are subject to diverse stress-causing factors such as academic demands and a highly competitive environment which may threaten their mental health. Objective. Identify the presence of depressive symptoms in medical students in a public university in Mexico. Method. Descriptive cross-sectional study of a random sample of 203 medical students at the Universidad Autónoma de Baja California from February to April 2018. The PHQ - 9 scale was used, and a cut-off score of $\geq 10$ was employed as positive for depressive symptoms. Basic descriptive statistics were utilized to analyze sociodemographic variables such as gender, academic advancement, stage of training (basic science vs. clinical), and the prevalence of the five different categories of the scale. Results. Of the medical students surveyed, $20.2 \%$ were found positive for depressive symptoms and $7.9 \%$ (16) had severe or moderately severe symptoms. Female gender increased the risk of presenting symptoms $(O R=3.5,95 \% \mathrm{Cl}[1.6$, 7.6]). Discussion. Despite the fact that the prevalence of depressive symptoms encountered was similar to that reported worldwide, it is troubling that one fifth of the surveyed students presented depressive symptoms. These results may justify implementation of preventive strategies by academic authorities to improve student mental health, and maybe even for early detection of risk of major depressive disorder.
\end{abstract}

Keywords: Medical students, depression, depressive symptoms.

\section{RESUMEN}

Introducción. Durante su formación profesional, los estudiantes de medicina están sometidos a diversos factores generadores de estrés como la exigencia académica y un entorno altamente competitivo, lo cual podría llegar a ser adverso para su salud mental. Objetivo. Identificar la presencia de síntomas depresivos en estudiantes de medicina de una universidad pública mexicana. Método. Estudio transversal, descriptivo, que se realizó con una muestra aleatoria de 203 estudiantes de medicina de la Universidad Autónoma de Baja California de febrero a abril de 2018. Se utilizó el cuestionario $\mathrm{PHQ}$ - 9 tomando el punto de corte $\geq 10$ como positivo para síntomas depresivos. Para el análisis de datos se utilizó estadística descriptiva; se estimaron proporciones de las variables sociodemográficas como género, semestre cursado, etapa básica o disciplinar y prevalencias de las diferentes categorías de la escala. Resultados. Se encontró una prevalencia de $20.2 \%$ de estudiantes de medicina con presencia de síntomas depresivos y el $7.9 \%$ reportó síntomas graves o moderadamente graves. Pertenecer al género femenino resultó ser un factor que incrementa las posibilidades de presentar síntomas depresivos $(O R=3.5$, IC 95\% [1.6, 7.6]). Discusión. A pesar de que la prevalencia de síntomas depresivos encontrada fue similar a lo reportado a nivel mundial, preocupa que una quinta parte de los encuestados presentaran síntomas depresivos. Estos resultados podrían permitir justificar a las autoridades académicas y a la comunidad estudiantil la implementación de estrategias preventivas para el mejoramiento de la salud mental de los estudiantes e incluso quizá detectar en forma temprana el riesgo de presentar un trastorno depresivo mayor.

Palabras clave: Estudiante de medicina, depresión, síntomas depresivos. 


\section{INTRODUCTION}

According to the World Health Organization, depression is the third largest cause of morbidity among adolescents, with suicide being the second leading cause of death between 15 and 29 year olds. Furthermore, detrimental use of alcohol and illegal drugs among adolescents is a large problem in many countries, which may lead to risky behaviors such as unsafe sex and reckless driving (WHO, 2018). Nevertheless, only a small percentage of cases are diagnosed due to the lack of training among healthcare workers or lack of symptom recognition by patients (Gutiérrez Rodas, Montoya Vélez, Toro Isaza, Briñón Zapata et al., 2010). Multiple studies have found that the prevalence of mild depression varies between $9 \%$ and $24 \%$, moderate depression between $5 \%$ and $15 \%$, and severe between $2 \%$ and $6.3 \%$. With respect to gender, reviewed studies found a predominantly female prevalence (Gollust, Eisenberg \& Golberstein, 2008; Bayram \& Bilgel, 2008; Riveros, Hernández, \& Riviera, 2007; Royal College of Psychiatrists, 2011).

The National Survey of Drug Use and Health (NSDUH) has been monitoring annually since 2004 the clinical level of depression among adolescents and the results have been surprising with respect to the increase in depression in such a short period of time: the proportion of adolescents between 12 and 17 who experienced at least one episode of severe depression in 2015 was $56 \%$, higher than in 2010 (Twenge, 2017).

During university training, medical students are subjected to diverse stress-inducing factors that can threaten mental health. Many are inherent to student life, such as academic demands and a highly competitive environment, as well as new interpersonal relationships, such as those with authority figures in the teaching-learning process (Baldassin, Alves, De-Andrade, \& Noqueira-Martins, 2008). The onslaught of these adverse elements will be well handled (or not) principally based on personal assets and the level of mental health of each student.

Current studies describe various factors that affect university students, such as economic instability, separation from parents, academic achievement, stressful situations, and the loss of loved ones (Henriques, 2014). Low self-esteem, the perception of poor social support from friends and family, and inefficient problem-solving skills are also risk factors associated with depression (Eskin, Ertekin, Harlak, \& Dereboy, 2008). Furthermore, it has been noted that self-identified stress among medical students correlates negatively with academic achievement - that is, poor academic achievement may be a response to perceived stress, though not precisely caused thereby (Román, Ortiz, \& Hernández, 2008).

Nevertheless, it is common that depression among students be blamed almost exclusively on academic demands, though studies of adolescent students have shown that aca- demic demands have not changed much in the last few decades. In contrast, one new risk factor is being correlated with negative aspects of mental health or unhappiness: time spent in front of a screen (electronic devices and social networks), and it is believed that more screen time may lead to less social interaction, and consequently increased depression and unhappiness (Twenge, 2017).

On the other hand, diverse studies have shown that medical students, at the start of their career, do not present a greater burden of psychiatric morbidity when compared to students of any other discipline. However, during academic development, a progressive deterioration of mental health is clearly identified: incidence of depression and anxiety disorder increases, as does consumption of alcohol and other psychoactive substances. Cases of bulimia and suicidal ideation are also much higher than in cohorts of other academic programs (El-Gilany, Amr, \& Hammad, 2008; Roman et al., 2008).

In one systematic review and metha-analysis performed by the Education Institute of Harvard Medical School of 183 studies published through 2016 regarding prevalence of depression, depressive symptoms, or suicidal ideation in medical students in 43 countries, without language restriction, a general prevalence of depression or depressive symptoms of $27.2 \%$ was found (in 37933 of 122356 individuals studied), with a confidence interval (CI) of $95 \%$, between $24.7 \%$, and $29.9 \%$. The summary prevalence estimates varied from $9.3 \%$ to $55.9 \%$. All but one study relied on self-reporting instruments. Included in this systematic review were nine longitudinal studies that evaluated depressive symptoms before and after medical school $(n=2432)$, which demonstrated a mean absolute increase of symptoms of $13.5 \%$ (range: .6\% to $35.3 \%$ ). Prevalence estimates did not significantly differ between students in pre-clinical vs. clinical years (Rotenstein, Ramos, \& Torre, 2016).

In 2013, in Mexico 517 students in their first year at the Universidad Nacional Autónoma de México School of Medicine (UNAM) were evaluated through the CES-D (Center for Epidemiologic Studies - Depression) scale to identify the presence of depressive symptoms in medical students. Thus, $39.3 \%$ of the students were found to have depressive symptoms with scores exceeding 16 on the CES-D, though the authors admit that a score of 16 may include false positives. This study also identified increased incidence of symptoms among women as compared to men (Guerrero López, Heinze Martin, Ortiz de-León, Cortés Morelos et al., 2013).

In another study carried out in a private university in San Luis Potosi, Mexico, the Depression Risk Detection Scale (EDRD/DRDS) was used on a sample of 368 students. In this case, $28.3 \%$ of the sample were found positive for depressive symptoms (Sánchez-Armáss Cappello, Muñiz Rojas, Sánchez Juárez, \& Olvera León, 2016).

Given the above, it is important to perform studies in our geopolitical region to identify of the presence of symp- 
toms of depression in students currently enrolled in medical school, which may uncover scientific evidence that could lead to implement of programs for prevention of depression and increased psychological support for students.

\section{MATERIALS AND METHODS}

A cross-sectional survey was administered to medical students at the Universidad Autónoma de Baja California from February to April 2018. To select participants, we calculated a sample size of 255, from the total of 757 medical students enrolled in the previous year, with a 95\% CI of 5, using the Survey System software package, available online (Creative Research Center, https://www.surveysystem. com/sscalc.htm). Survey groups were randomized by first numbering academic groups and then selecting groups by lottery, being careful to obtain a proportional number of basic- and clinical- science students. Students included in the study were between 18 and 30 years of age, enrolled in medical school between the $1^{\text {st }}$ and $10^{\text {th }}$ semester. Students who reported having lost a loved one in the previous six months, had been previously diagnosed with a psychiatric illness, or were taking medication prescribed by a psychiatrist were excluded from the study.

To identify depressive symptoms, we applied the Spanish version of the PHQ-9 (Patient Health Questionnaire) Depression Scale, designed by Spitzer in 1999 (Kroenke, Spitzer, \& Williams, 2001), validated in Spanish by Baader in Chile in 2012, though previously used by two authors in Mexican populations (Martínez-Martínez, Muñoz-Zurita, Rojas-Valderrama, \& Sánchez-Hernández, 2016; Romo Nava, Tafoya, \& Heinze, 2013). The Chilean study demonstrated adequate construct and concurrent validity, with an $86.2 \%$ and $86.4 \%$ concordance between ICD-10 criteria and those found with and without major depression, respectively (Baader, Molina, Venezian, Rojas, Farías et al., 2012).

The PHQ-9 consists of nine items to evaluate the presence of depressive symptoms (corresponding with the DSM-IV criteria). It asks the subject to review the previous two weeks and report the number of days on which the symptom predominated. Each item has a corresponding severity index: $0=$ never, $1=$ some days, $2=$ more than half the days, and $3=$ almost daily. Scores can range from 0 to 27 , which is then translated into five levels of symptom severity: no risk (0 - 4), low (5 - 9), moderate (10 - 14), moderately severe (15 - 19), and severe (20 - 27). These categories correlate with the probability of presenting a major depressive episode; nevertheless, major depression is rarely seen in individuals with scores less than 10 . Scores $\geq 10$ are therefore commonly used as the cut-off to determine the presence of depressive symptoms (Kroenke et al., 2001). It is worth mentioning that in this study we used scores of $\geq 10$ as positive for depressive symptoms as well as grouping them according to severity categories previously mentioned.

The study protocol was approved by the Bioethics Committee of the School of Medicine and Psychology. Participants signed an informed consent, which stated the study objectives, expected amount of time to complete the questionnaire, that there would be no compensation for study participation, and that the information provided could contribute to improving preventative programs offered by the university. Participants were also informed that their information would be held strictly confidential and there would be no risk in their participation, assuring them that participation was voluntary and that there would be no negative consequences if they decided not to participate. Participants were also oriented to the existing services available through the university's Committee on Mental Health in the event they felt the need for psychological evaluation or intervention at any time.

\section{Data analysis}

We used basic descriptive statistics to analyze the data, calculating sociodemographic variables such as gender, years of study, basic science vs. clinical stage, and prevalence of the four different scale categories. For quantitative variables, we calculated central tendency and deviation through chi $^{2}$ and logistic regression, establishing $p \leq .05$ as statistically significant, all of which were managed through the statistical software package SPSS-21.

\section{RESULTS}

The PHQ-9 questionnaire was applied to 247 medical students between their first and tenth semester of university education during the spring 2018 semester. Forty-four students were excluded from the study: 27 for reporting having lost a loved one in the previous six months, six for having a previously diagnosed psychiatric illness, one for being currently treated by a psychiatrist, and ten for two or more of the above exclusion criteria, leaving a sample size of 203 students.

Of the total sample, 104 students $(51.2 \%)$ were male, and $99(48.8 \%)$ female; $52.7 \%(n=107)$ were in the basic science years (first through fifth semesters) and 47.3\% $(n=$ 96) in their clinical formation (sixth through tenth semesters). The age range of participants was 18 to 28 years, with a mean age of 20.9 years $( \pm 1.86)$. These sociodemographic characteristics are shown in Table 1.

We found a prevalence of $20.2 \%(n=41)$ (PHQ-9 $\geq 10)$ of medical students with depressive symptoms, that could suggest a major depressive episode. There was no statistical difference in greater or lesser depressive symptoms between participants in basic sciences and those in their clin- 
Table 1

Sociodemographic characteristics of medical students surveyed at a public university in Mexico, 2018

\begin{tabular}{lcclll}
\hline \multicolumn{1}{c}{$n$} & $(\%)$ & Semester & $n$ & $(\%)$ \\
\hline Gender & & & & & \\
Masculine & 104 & $(51.2 \%)$ & First & 21 & $(10.3)$ \\
Femenine & 99 & $(48.8 \%)$ & Second & 24 & $(11.8)$ \\
Age & & & Third & 21 & $(10.3)$ \\
$\quad$ Minimum & 28 years & Fourth & 22 & $(10.8)$ \\
Maximum & 18 years & Fifth & 19 & $(9.4)$ \\
Mean & $20.9( \pm 1.86)$ & Sixth & 17 & $(8.4)$ \\
Median & 21 years & Seventh & 19 & $(9.4)$ \\
Professional area & & & Eighth & 24 & $(11.8)$ \\
$\quad$ Basic Science & 107 & $(52.7 \%)$ & Ninth & 20 & $(9.9)$ \\
Clinical Science & 96 & $(47.3 \%)$ & Tenth & 16 & $(7.9)$ \\
\hline
\end{tabular}

ical years (Table 2). We also found no correlation between participants' age and their PHQ-9 scores.

With respect to the severity of the depressive symptoms, $41.9 \%(n=85)$ referred absence of depressive symptoms, $37.9 \%(n=77)$ mentioned mild symptoms, $12.3 \%(n=25)$ had moderate symptoms, $5.9 \%(n=12)$ moderately severe symptoms, and $2 \%(n=4)$ severe depressive symptoms. Bivariate analysis showed a statistically significant difference in depressive symptoms among female participants, and in fact all four cases of severe depressive symptoms were female (Table 3).

Although multivariate analysis with logistic regression, using presence of depressive symptoms (i.e., students scoring 10 or more on the PHQ-9) as the dependent variable, and risk factors of age, gender, and semester of study were performed to evaluate the influence of said factors, the statistically significant predominance of the female gender $(O R=3.5$; CI 95\% [1.6,7.6]) persisted. Female students are 3.5 times more likely to develop depressive symptoms than their male counterparts (Table 3 ).

In Figure 1, the answer trends of each of the nine questions of the PHQ-9 scale are shown. The arithmetic mean of each response, along with its $95 \%$ confidence interval, is displayed. Possible responses went from "zero"
Table 2

Comparison of the severity of depressive symptoms by gender in medical students in a public university in Mexico

\begin{tabular}{|c|c|c|c|c|c|c|}
\hline \multirow[b]{3}{*}{ Symptom severity } & \multicolumn{4}{|c|}{ Gender } & & \\
\hline & \multicolumn{2}{|c|}{ Masculine } & \multicolumn{2}{|c|}{ Femenine } & \multicolumn{2}{|c|}{ Total } \\
\hline & $n$ & $\%$ & $n$ & $\%$ & $n$ & $\%$ \\
\hline None & 51 & 49.0 & 34 & 34.3 & 85 & 41.9 \\
\hline \multicolumn{7}{|l|}{ Depressive symptoms } \\
\hline Mild & 41 & 39.4 & 36 & 36.4 & 77 & 37.9 \\
\hline Moderate & 8 & 7.7 & 17 & 17.2 & 25 & 12.3 \\
\hline Moderately severe & 4 & 3.8 & 8 & 8.1 & 12 & 5.9 \\
\hline Severe & 0 & 0 & 4 & 4.0 & 4 & 2 \\
\hline Total & 104 & 100 & 99 & 100 & 203 & 100 \\
\hline
\end{tabular}

Notes: Pearson $\mathrm{Chi}^{2}=12.182 ; p=.016$.

to "almost every day," scaled 0 to 3 , and the mean response varied from .2 to 1.3 , with most questions having a mean score less than 1 . However, question 4 (regarding tiredness) had a mean score of 1.3, and question 9 (regarding suicidal ideation) had the lowest score, where 33 people $(16.3 \%)$ responded affirmatively, of which $2 \%$ (four people) reported having these ideas almost every day; $1.5 \%$ (three people) more than half of the days; and $12.8 \%$ (26 people) on several days.

\section{DISCUSSION AND CONCLUSION}

This study found a prevalence of depressive symptoms in medical students of $20.2 \%$, which is close to the $27.2 \%$ reported worldwide in the previously mentioned meta-analysis (Rotenstein et al., 2016), which included 43 countries. Furthermore, we also compared the prevalence calculated by each different survey tool, and among the 15 studies using the PHQ-9 scale, a prevalence of $18.3 \%$ was found, which is very similar to our findings.

With respect to the different survey instruments and the measurements they afford, in Mexico it is common to use the Beck Depression Inventory (BDI) (Fouilloux Morales, Barragán Pérez, Ortíz León, Jaimes Medrano et al., 2013),

Table 3

Interaction of characteristics of medical students in a public university in Mexico with and without depressive symptoms

\begin{tabular}{lcccccccc}
\hline $\begin{array}{l}\text { Risk factors } \\
\text { for depressive } \\
\text { symptoms }\end{array}$ & \multicolumn{1}{c}{ W } & SE & Statistic & $d f$ & Sig. & OR & Inferior & Superior \\
\hline Group & -.113 & .100 & 1.270 & 1 & .260 & .893 & .734 & 1.087 \\
Age & .252 & .154 & 2.691 & 1 & .101 & 1.287 & .952 & 1.739 \\
Gender & 1.263 & .391 & 10.424 & 1 & .001 & 3.535 & 1.642 & 7.607 \\
Constant & -8.068 & 3.056 & 6.968 & 1 & .008 & .000 & - & - \\
\hline
\end{tabular}

Notes: $\mathrm{B}=$ Regression coefficient; $\mathrm{SE}=\mathrm{Standard}$ error; $\mathrm{df}=$ Degrees of freedom; Sig = Level of significance; OR = Odds Ratio; $\mathrm{Cl}$ 95\% = 95\% Confidence Interval. 


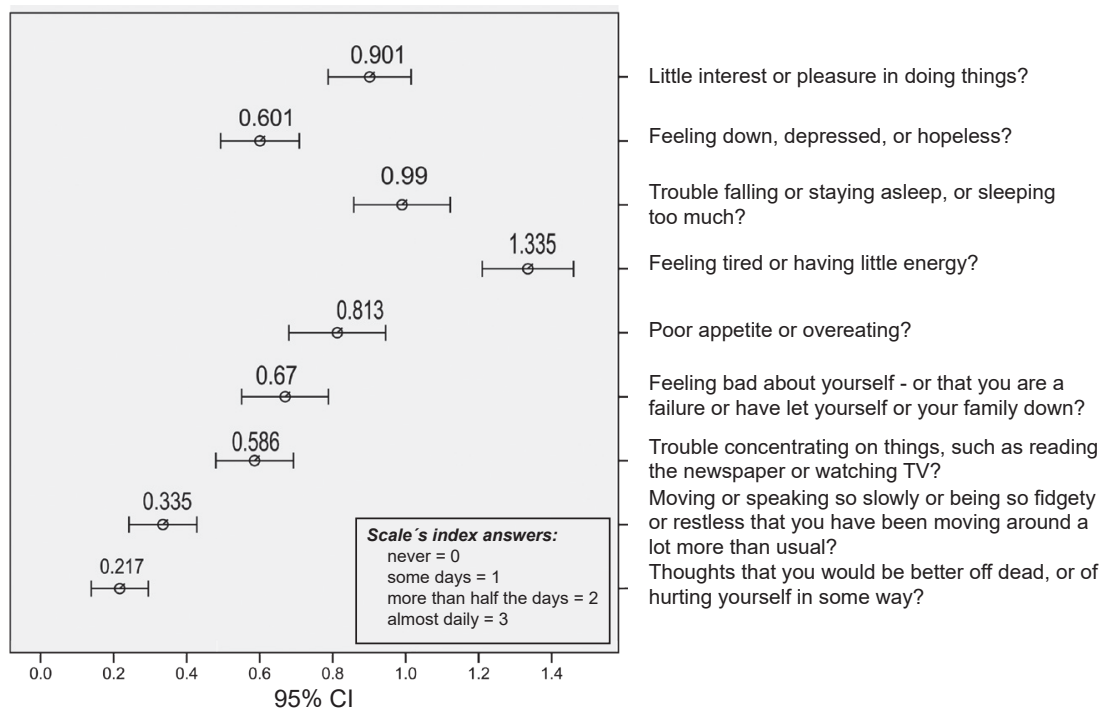

Figure 1. Answers trends to PHQ-9 Scale among medical students in a public university in Mexico.

the Zung's Depression Scale (Palmer Morales, Prince Vélez, Medina Ramírez, \& López Palmer, 2017), the Center for Epidemiologic Studies Depression Scale (CES-D) (Guerrero López et al., 2013), or the PHQ-9 scale (Romo Nava et al., 2013) to study this subject, with very diverse findings. For example, in the Romo Nava study, where they utilized the same threshold as in our study, they report a depressive symptoms prevalence considerably lower than ours, and found symptom prevalence positively correlated with academic advancement (Romo Nava et al., 2013).

On the other hand, our results were similar to those reported by Fouilloux Morales et al. (2013), who used the Beck Depression Inventory (BDI) and found a prevalence of $23 \%$, with females being more affected, as well as finding that $68 \%$ of those students affected had failed at least one class.

One consistent finding is that being female increases the risk of presenting depressive symptoms, a finding that is borne out in other Latin American studies such as those by Villacura, Irarrázabal, and Lopez (2017) in Chile, and Sarabia Arce (2017) in Peru.

Other studies that employed the BDI, Zung's Depression Scale, or the PHQ-9 included findings on suicidal ideation. For example, Puthran, Zhang, Tam, \& Ho (2016) reported a mean of 5.8\%, whereas Rotenstein et al. (2016) found $11.1 \%$. In our study we observed positive response to suicidal ideation in $16.3 \%$ of students, but we must be cautious when making a diagnostic interpretation in the fact that there was only one item that explored that ideation.

The differences in reported prevalence can be explained by the differences between the scales used in each study, as well as the time period each scale evaluates. For example, in our study the instrument used considered symptoms during the two weeks prior to the survey, whereas Zung's scale evaluates suicidal ideation in recent days, and the BDI investigates them at the survey moment (Sarabia Arce, 2017).

Limitations of this study include cross-sectional design in which data was collected at a single moment in time, though that data may vary with time in the life of the person. Another important limitation is the variety of instruments available, as well as the threshold for positive results, which make precise comparison difficult. Despite this, for our study we felt that the PHQ-9 was a useful and reliable instrument, given the sensitivity and specificity previously demonstrated (Baader et al., 2012). Furthermore, it allows us to evaluate the severity of depressive symptoms, though we should emphasize it is only a screening instrument, not diagnostic, and a high score only refers to the probability of presenting major depressive disorder (Kroenke et al., 2001). Nevertheless, we believe this study achieved a sufficiently random sample, with an equitable distribution with respect to gender and the different stages of academic advancement, being careful to exclude subjects with recent major loss, with preexisting psychiatric diagnoses, or in the midst of exams. We therefore believe that our findings can be generalized to similar student populations in other universities, and can be taken as a starting point for future studies.

Finally, it is important to mention that the objective of any study should be to contribute to the body of scientific evidence that, above all, demonstrates the existence of a problem. Through the use of a screening tool, this study has demonstrated that one-fifth of the surveyed population presented depressive symptoms, and these results justify the implementation, on the part of interested academic authorities and the student body, of strategies whose goal is to protect and improve the mental health of medical students, and 
thus contribute to improving such challenges as academic attrition, poor academic achievement, and early detection of risks for developing major depressive disorder.

\section{Financing}

None

\section{Conflicts of interest}

The authors report no conflicts of interest.

\section{REFERENCES}

Baader-M, T., Molina-F, J. L., Venezian-B, S., Rojas-C, C., Farías-S, R., FierroFreixenet, C., ... \& Mundt, C. (2012). Validación y utilidad de la encuesta PHQ9 (Patient Health Questionnaire) en el diagnóstico de depresión en pacientes usuarios de atención primaria en Chile. Revista Chilena de Neuropsiquiatría, 50(1), 10-22.

Baldassin, S., Alves, T. C., De-Andrade, A. G., \& Noqueira-Martínez, L. A. (2008). The characteristics of depressive symptoms in medical students during medical education and training: a cross-sectional study. BMC Med Educ, 8:60 doi: 10.1186/1472-6920-8-60

Bayram, N. \& Bilgel, N. (2008). The prevalence and socio-demographic correlations of depression, anxiety and stress among a group of university students. Soc. Psychiatry Psychiatr Epidemiol, 43(8), 667-672. doi: 10.1007/s00127-0080345-x

El-Gilany, A.-H., Amr, M., \& Hammad, S. (2008). Perceived stress among male medical students in Egypt and Saudi Arabia: Effect of sociodemographic factors. Ann Saudi Med, 28(6), 442-448. doi: 10.5144/0256-4947.2008.442

Eskin, M., Ertekin, K., Harlak, H., \& Dereboy, C. (2008). Prevalence and factors related to depression in high school students. Turk Psikiyatri Derg, 19(4), 382389.

Fouilloux Morales, C., Barragán Pérez, V., Ortíz León, S., Jaimes Medrano, A., Urrutia Aguilar, M. E., \& Guevara-Guzmán, R. (2013). Síntomas depresivos y rendimiento escolar en estudiantes de Medicina. Salud Mental, 36(1), 59-65.

Gollust, S. E., Eisenberg, D., \& Golberstein, E. (2008). Prevalence and correlates of self-injury among university students. J Am Coll Health, 56(5), 491-498. doi: 10.3200/JACH.56.5.491-498

Guerrero López, J. B., Heinze Martin, G., Ortiz de-León, S., Cortés Morelos, J., Barragán Pérez, V., \& Flores-Ramos, M. (2013). Factores que predicen depresión en estudiantes de medicina. Gaceta Médica de México, 149(6), 598604.

Gutiérrez Rodas, J. A., Montoya Vélez, L. P., Toro Isaza, B. E., Briñón Zapata, M. A., Rosas Restrepo, E., \& Salazar Quintero, L. E. (2010). Depresión en estudiantes universitarios y su asociación con el estrés académico. Revista CES Medicina, 24(1), 7-17.

Henriques, G. (2014). Today's college students are suffering from an epidemic of mental illnesses. The College Student Mental Health Crisis. Theory of Knowledge. Retrieved from: https://www.psychologytoday.com/us/blog/ theory-knowledge/201402/the-college-student-mental-health-crisis
Kroenke, K., Spitzer, R. L., \& Williams, J. B. (2001). The PHQ-9: validity of a brief depression severity measure. J Gen Intern Med, 16(9), 606-613. doi: 10.1046/j.1525-1497.2001.016009606.x

Martínez-Martínez, M. C., Muñoz-Zurita, G., Rojas-Valderrama, K., \& SánchezHernández, J. A. (2016). Prevalencia de síntomas depresivos en estudiantes de la licenciatura en medicina de Puebla, México. Atención Familiar, 23(4), 145 149. doi: 10.22201/facmed.14058871p.2016.4.57356

Organización Mundial de la Salud. (2018). Los jóvenes y la salud mental en un mundo en transformación: Día Mundial de la Salud Mental 2018. Retrieved from: http://www.who.int/mental_health/world-mental-health-day/2018/es/

Palmer Morales, Y., Prince Vélez, R., Medina Ramírez, M. C., \& López Palmer, D. A. (2017). Frecuencia de rasgos de depresión en médicos internos de pregrado del Instituto Mexicano del Seguro Social en Mexicali, Baja California. Investigación Educación Médica, 6(22), 75-79. doi: 10.1016/j.riem.2016.08.001

Puthran, R., Zhang, M. W., Tam, W. W., \& Ho R. C. (2016). Prevalence of depression amongst medical students: A meta-analysis. Medical Education, 50(4), 456468. doi: $10.1111 /$ medu. 12962

Riveros, M., Hernández, H., \& Riviera, J. (2007). Niveles de depresión y ansiedad en estudiantes universitarios en Lima metropolitana. Rev Investig Psicol, 10(1), 91-102. doi: 10.15381/rinvp.v10i1.3909

Román, C., Ortiz, F., \& Hernández, Y. (2008). El estrés académico en estudiantes latinoamericanos de la carrera de medicina. Revista Iberoamericana de Educación, 46(7), 1-8. doi: 10.35362/rie4671911

Romo Nava, F., Tafoya, S., \& Heinze, G. (2013). Estudio comparativo sobre depresión y los factores asociados en alumnos del primer año de la Facultad de Medicina y del Internado. Salud Mental, 36(5), 375-379.

Rotenstein, L. S., Ramos, M. A., Torre, M., Segal, J. B., Peluso, M. J., Guille, C., ... \& Mata, D. (2016). Prevalence of depression, depressive symptoms and suicidal ideation among medical students: A systematic review and meta-analysis. JAMA, 316(21), 2214-2236. doi: 10.1001/jama.2016.17324

Royal College of Psychiatrists. (2011). The mental health of students in higher education. Callender, J., Fagin, L., Jenkins, G., Lester, J., \& Smith, E. (Eds.). College Report CR166. Retrieved from: https:/www.nightline.ac.uk/sites/ default/files/The $\% 20$ Mental $\% 20$ Health $\% 20$ of $\% 20$ Students $\% 20$ in $\% 20$ Higher\%20Education\%20-\%20Royal\%20College\%20Psychiatrists $\% 202011$. pdf

Sánchez-Armáss Cappello, O., Muñiz Rojas, L., Sánchez Juárez, C., \& Olvera León, G. (2016). Evaluación de un instrumento de tamizaje para la detección de depresión en estudiantes universitarios. Revista Electrónica de Psicología Iztacala, 19(4), 1426-1442.

Sarabia Arce, S. (2017). Sintomatología depresiva según PHQ-9 y rendimiento académico en estudiantes de primero a quinto año de medicina. (Tesis de Maestría), Universidad Peruana Cayetano Heredia, Lima, Perú. Retrieved from: http://repositorio.upch.edu.pe/bitstream/handle/upch/838/Sintomatologia SarabiaArce_Silvana.pdf? sequence $=1 \&$ isAllowed $=\mathrm{y}$

Twenge, J. M. (2017). iGen Why Today's Super-Connected Kids Are Growing Up Less Rebellious, More Tolerant, Less Happy-and Completely Unprepared for Adulthood. New York: ATRIA Books.

Villacura, L., Irarrázabal, N., \& López, I. (2017). Evaluation of depressive and anxiety symptomatology in medical students at the University of Chile. Mental Health \& Prevention, 7, 45-49. doi: 10.1016/j.mhp.2017.06.001 